\title{
Leadership Implementation in Muhammadiyah University: A Phenomenology Study at University of Muhammadiyah Malang
}

\author{
Mursidi \\ University of Muhammadiyah Malang \\ mursidi@umm.ac.id
}

\begin{abstract}
This study aims to identify the leadership style and the strategy used by the leader in satisfying both internal and external stakeholders. Leadership variables function as a strategy to shift the role of the university from a market follower to a market leader. This is a phenomenology using qualitative method proposed by Edmund Husserl who argues that subjective thinking asses the actual facts beyond the visible symptoms to find the hidden meaning. UMM's success is an actual phenomenon, and the leaders' interpretations on their leadership style will be discussed further in this paper. The following leadership styles were observed: 1) prophetic leadership by exercising sidiq (truthfulness), tabbligh (trustworthiness), amanah (advocacy) and fatonah (wisdom); 2). communal leadership: cultural, collective and collegial; 3). Activist leadership: organization promotor, which was shared by MF and ME, and 4). Linear and dynamic leadership: futuristic, flexible and rational. The implementation of linear leadership is manifested through progressive change to a better direction. It is mainly influenced by standardization/regulation made by the government and Muhammadiyah organization. This type of leadership was seen in the 2000s during the leadership transition.
\end{abstract}

Keywords: leadership, prophetic, phenomenology.

\section{INTRODUCTION}

A good and adequate organizational strategy is not the only predictor of organization success. A good leadership is also required to achieve the objectives of the organization. Thus, an ideal leader has the ability not only to make an effective strategy, but also to realize it.

That being said, each organization consists of various elements that have different functions but are expected to equally perform their roles in a collegial manner so no one is more dominant or more important than the others, unless stated otherwise in the predetermined objectives.

Hence, a higher education institution should perform its function and work based on the organization principle. A university is a manifestation of a set of elements that must be well managed and mobilized to achieve the expected goal.

Similarly, as an Islamic university established under the auspices of Muhammadiyah, UMM has been mandated to be a learning center to create high quality human beings who practice Islamic values. This is in line with the philosophy, goal, process and human resource that require the presence of a leader who has the ability, competence and high integrity in achieving the goals.

Historically, the leadership of this University has proven to be successful in making UMM the largest and outstanding Muhammadiyah University. Consequently, UMM has been appointed a PTM Pembina for Eastern Indonesia. UMM has followed half of the history of its parent organization (Persyarikatan Muhammadiyah), which was founded by KH Ahmad Dahlan. The organization has been here for more than a century and become the oldest community organization that continues to exist and develop. In this case, UMM has contributed to support Muhammadiyah.

Considering the foregoing, the following research questions were created: 1) how does the UMM leader understand and interpret his leadership style? 2). how is the interpretation implemented as a strategy to satisfy all stakeholders (both the internal and external ones)?, and 3) what leadership variables has emerged as a strategy that bring UMM from a market follower to become a market leader?

\section{METHOD}

This study used qualitative approach. Essentially, in a qualitative research, a researcher observes people in his environment, interacts with them, and tries to understand their language and interpretation of their surroundings.

With qualitative methods, more complete, in-depth, reliable and meaningful data can be obtained, so that the objectives of the study can be achieved. Although it is not a new method, but the answer to the problem can be sought more quickly. On the contrary, quantitative method requires empirical and measurable data. Invisible facts that cannot be captured by senses are difficult to reveal. Thus, using qualitative method, a comprehensive data with high credibility can be obtained. 
This study uses Husserl's phenomenological approach by examining the structure of the intensity of consciousness and formulating the four activities that are inherent in consciousness, namely: 1) objectification; 2) identification; 3) correlation, and 4) constitution. The main research instrument is the researcher himself, but in order to expand the focus of the research, simple research instruments were developed to sharpen and complement the data from the observation. There were two instruments used, first, an instrument to rank the University's achievements and second, an instrument to identify factors influencing the achievement.

\section{Data Collection, Data Analysis and Participant}

In a qualitative research, the data source was chosen purposively. The selection of data sources is usually temporary and will develop later when the research is carried out in the research field. Sources of data are determined by selecting people who have the power and authority on social situations or the objects being studied, so as to "open the door" for the researchers in the data collection. Borrowing Spradly's advice, Faisal suggests that the social situation chosen for the initial sample is a social situation that becomes a primary source of many other domains. He further suggests that a researcher choose participants or informants who meet this criteria. The key informants in this study were A Malik Fadjar (MF) and Muhadjir Effendy (ME).

\section{RESULT}

Leadership at UMM is exercised simultaneously in line with the university development. In the early days, the leadership style applied in UMM was a simple, collective-collegial leadership with constant hard work to achieve goals. Today, as a market leader, a formal and dynamic system is more prominent to be a respected university. Below is the interpretation of leadership style of MF and ME.

\section{Exemplary Leadership of Rosulullah Muhammad SAW.}

As an Islamic university, UMM creates an ideology based on transformative prophetic teaching. In this case, Rector as the top leader used the teachings and example of Prophet Muhammad SAW as a reference. It was reflected in the leadership style of $\mathrm{MF}$ and $\mathrm{ME}$ that referred to AR Fachruddin by implementing the values of sidiq (truthfulness), tabbligh (trustworthiness), amanah (advocacy) and fatonah (wisdom). It resonates with Brillianto's (2011) finding. MF encouraged modesty and simplicity, which were reflected in the lenient supervision during his administration. MF put more emphasis on mutual trust and self-control of the subordinates.

\section{Communal Leadership: Cultural, Collective and Collegial}

Communal leadership was observed back in early days when UMM was managed traditionally and influenced by less professional management. Despite the conventional management, it adopted more cultural, dynamic and familial leadership style. In addition, it also enforced collective and collegial manner, which was embedded in Muhammadiyah organization.

Communal leadership was also found when UMM was still pioneering as it was still heavily dependant on the parent organization of Muhammadiyah Regional Executive (PDM) of Malang. Structurally, the University used to work together with the PDM, and human resources were 'borrowed' from other campuses or agencies. Therefore, communal leadership was suitable for this situation.

\section{Activist Leadership: Organization Promotor}

Activist leadership style was shared by MF and ME who equally had an experience as an activist, which helped to promote the organization. The activist style was characterized by great dreams enforced through discussions, which was further implemented with high spirit and energy.

While MF showed his capacity as an alumni of a developed country (the United States) and dreamed that his campus would be as big (by constantly reinforcing the dream to his subordinates through a routine forum as a means of 'mental revolution'), ME made prominent changes through journalist leadership, which was 'out of the box' and extremely dynamic. Both of the leaders displayed hard work and discipline quality and showed constant innovation in their leadership.

\section{Linear and Dynamic Leadership: Futuristic, Flexible and Rational.}

Linear leadership was manifested in a progressive change to a better direction. It is mainly influenced by standardization/regulation made by the government and Muhammadiyah organization. This type of leadership was seen in the 2000s during the leadership transition from MF's to ME's administration. During this time, UMM began to strengthen the internal system and adapt to the regulation from higher authority. To achieve balance in this leadership, dynamic style was also adopted. 


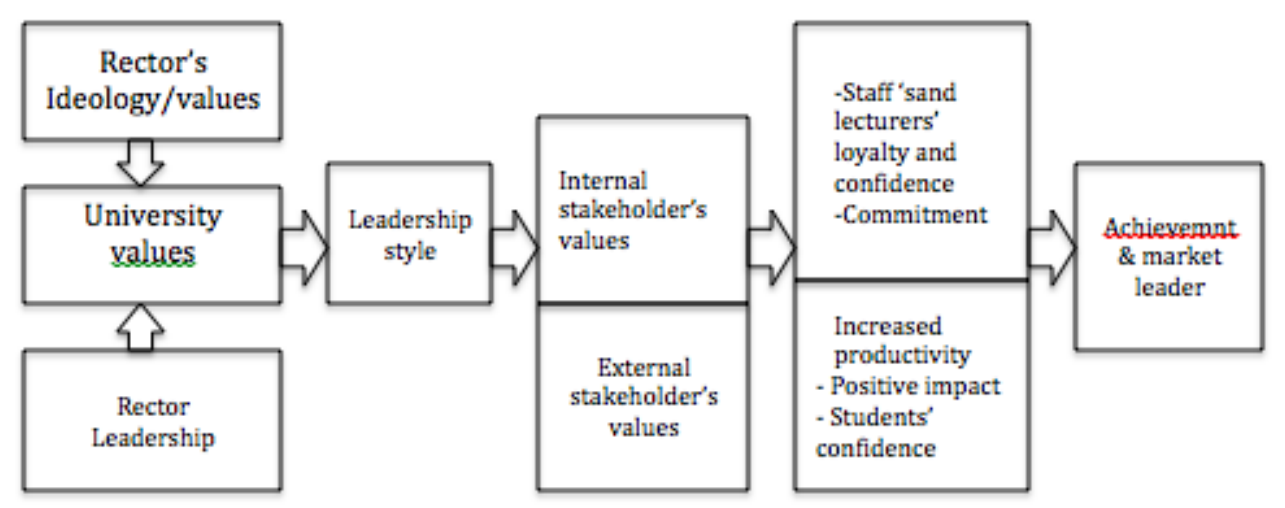

Figure 1: Leadership model beneficial for the stakeholders

ME adopted the leadership style of a soccer team manager in observing the change in the current situation and internal dynamics of his institution. However, he sometimes acted like a 'Kostrad' by being assertive to his subordinates, especially regarding task completion. He also implemented the philosophy of hulubis kuntul baris to place himself in front, in the middle or behind his subordinates.

Both MF and ME had uniqueness in their leadership style. The combination of these uniquenesses made a strong organization and greatly impacted on UMM progress and its current position as a market leader.

These leadership styles were greatly influenced by the values held by the Rector, which later became the values of the University. These values might also benefit the stakeholders and bring out valuable qualities like loyalty and confidence in lecturers, employees, and also students; and resulted in improved productivity of the university and shifted its position from market follower to market leader.

\section{CONCLUSION}

The leadership in UMM holds the ideology of Muhammadiyah and refers to the example of Prophet Muhammad SAW by implementing the positive values including sidiq (truthfulness), tabbligh (trustworthiness), amanah (advocacy) and fatonah (wisdom). Muhammadiyah ideology is a belief system and aspiration of Muhammadiyah encompassing its journey as an Islamic movement in realizing the true Islamic community as part of amar ma'ruf nahi munkar (commanding the good and forbidding the evil) (Budget Basic Muhammadiyah, 2005).

It is hoped that the results of this study bring some advantages to the stakeholders (both the internal and external ones) and provide input for the future University leaders in exercising their leadership by using the proposed strategy to bring the university to a higher position level in the future.
The results of this study can also be used as a leadership model in Higher Education under the auspices of Muhammadiyah.

Finally, the findings provide theoretical contribution to the development of science related to Human Resource Management and Leadership and suggest alternative theories on leadership studies applied at University of Muhammadiyah Malang (UMM) and other Muhammadiyah universities in indonesia, not to mention the newly established ones.

The variables emerged in the leadership style serves as a strategy that can bring the university to higher position from market follower to market leader and improve professionalism. The variables include expertise, social responsibility and corporateness.

\section{Reference}

[1] Alimuddin, 2002, Pengaruh Gaya Kepemimpinan terhadap Kinerja Pegawai Badan Pengawasan Daerah Kota Makassar, Tesis, Program Pasca Sarjana Magister Manajemen Universitas Gajah Mada (tidak dipublikasikan)

[2] Anggaran Dasar Muhammadiyah, 2005, Mu'tamar Muhammadiyah, PP Muhammadiyah.

[3] Bass, B. M., \& Avolio, B. J. 1994. Improving organizational effectiveness through transformational leadership. Thousand Oaks, CA: Sage.

[4] Bass, B. M. 1985. Leadership and performance beyond expectations. New York: The Free Press.

[5] Griffin., Ricky W. 1980, "Relationships Among Individual, Task Design, and Leader Behavior Variables", Academy of Management Journal, Vol. 23, No. 4, 665-683.

[6] Locke., E. A., 1997. Esensi Kepemimpinan, terjemahan. Jakarta: Mitra Utama

[7] Lok and Crawford. 2004. "The effect of organizational culture and leadership style on job satisfaction and organizational commitment acrossNational Comparison", The Journal of Management Development, Vol. 23, No. 4, 321-337. 
[8] Luthans., Fred. 2006. Perilaku Organisasi, Edisi Sepuluh, Yogyakarta: Penerbit Andi

[9] Marzuki., Sukarno. 2002. Analisis Pengaruh Perilaku Kepemimpinan terhadap Kepuasan Kerja dan Kinerja Account Officer: Studi Empirik pada Kantor Cab BRI di Wilayah Jawa Timur, Tesis, Program Pasca Sarjana Magister Mana-jemen Universitas Diponegoro (tidak dipublikasikan)

[10] Mas'ud., Fuad. 2004. Survai Diagnosis Organisasional Konsep dan Aplikasi, Semarang: Badan Penerbit-UNDIP

[11] McNeese-Smith., Dona. 1996. "Increasing Employee Productivity, Job Satisfaction and Organizational Commitment", Hospital and Health Services Adminis-tration, Vol.41, No.2, pp.160-175

[12] Menon., Maria E. 2002. "Perceptions of Pre-Service and In-Service Teachers Regarding the
Effectiveness of Elementary School Leadership in Cyprus", The International Journal of Educational Management, 16 February, p.91-97.

[13] Ostroff., C. 1992. "The Relationship Between Satisfaction Attitudes and Perfor-mance an Organization Level Analysis", Journal of Applied Psychology. Vol. 77. No. 68. p. 933-974

[14] Su'ud., Muh. 2000. "Persepsi Sosial Tentang Kredibilitas Pemimpin”, Sinergi Kajian Bisnis dan Manajemen, Vol. 3, No.1. Hal 51-65 